\title{
Evaluation of Ground Arthropod Structure in Restoration Area of Talangagung Landfill as Edutourism Attraction, Kepanjen, Malang
}

\author{
Dinda Azalia $^{1^{*}}$, Hendra Setiawan $^{1}$, Catur Retnaningdyah ${ }^{2}$ \\ ${ }^{1}$ Master Program of Biology, Faculty of Mathematics and Natural Sciences, University of Brawijaya, Malang, Indonesia \\ ${ }^{2}$ Department of Biology, Faculty of Mathematics and Natural Sciences, University of Brawijaya, Malang, Indonesia
}

\begin{abstract}
Aim of this research is to know the composition, community structure and survival of ground arthropod in restoration area of Talangagung edutourism landfill (TPA Wisata Edukasi Talangagung). Arthopod survey was conducted with four methods, yellow pan trap, pit fall trap, berlesetullgren, and sweep net. The research was done in four different locations with twice repetition. Survey location was divided in three zone, which is zone one with 10 years restoration, zone two with five years restoration, and zone three which not yet restored, and reference site. Abiotic factor which observed in this research such as light intensity, humidity, and air temperature. Analysis of arthropod diversity and community structure in each site was calculated from importance value index (IVI) and diversity index (Shannon Wienner Index). The results show that diversity of ground arthropod in zone one, two, three, and reference site was on medium level which each score 1.9, 1.87, 1.71, and 2.08. Community structure with dominant pattern showed with IVI from Acrididae in zone one and zone three with IVI $67.2 \%$ and $53.5 \%$. Myrmicidae in reference site dominance with IVI $51.4 \%$ and Formicidae in zone one with IVI $48.6 \%$. Ground arthropod in zone one and reference site had similarity in community structure which showed in same cluster in biplot analysis and zone two and three was in another different cluster.
\end{abstract}

Keywords: Arthropod, diversity, restoration, community structure

\section{INTRODUCTION}

The increase of population in the world was affected to increase of total waste which produce every years, especially in urban area. The increase of total waste is not followed with increase of waste management infrastructure. It made waste management become more complex. Indonesia with total population more than 230 million people has a problem with waste management. Landfill in Indonesia is still use open dumping system to manage waste. Open dumping is waste management system which put the waste carelessly and after it is full, landfill will be ignored. Open dumping system can make contamination to environtment [1].

Talangagung edutourism landfill (TPA Wisata Edukasi Talangagung/TPA WET) is a landfill which located in District Kepanjen, Malang Regency, East Java. TPA WET can accommodate waste from eight districts in Malang Regency with total total number of population about 2.7 milion people. TPA WET accommodates 4.800 households with total waste $140 \mathrm{~m}^{3}$ per day. Dump truck was used to transport waste to TPA WET. TPA WET is devided into three zone based

\footnotetext{
${ }^{*}$ Correspondence address:

Dinda Azalia

Email : moliydadinda@yahoo.co.id

Address : Master Program of Biology, University of Brawijaya, Veteran Malang 65145
}

on restoration time per area. Zone one is an area with 10 years restoration. Zone two with five years restoration, and zone three which still used as open dumping area.

Restoration is a preventive action from environmental threats and to empower conservation factor for conservation in degradated area. Aim of restoration is to restore some area into former condition like in the past [2]. Restoration activities in degradated area depend on diversity of plants species and availability of seeds [3]. Restoration activity in landfill former of TPA WET is one of efforts from settlements and local government to reduce environmental contaminant which causeed by open dumping system. Restoration activities give some benefits to settlements from economic sector and their ecological services. In economic sector, TPA WET was designed as edutourism destination and camping ground for public, which make benefits to settlements. Moreover, TPA WET was provided an installation of methane gas from open dumping waste area as energy source for settlements. But, until this day, data from ecological services of restoration activities in TPA WET is still unknown.

Arthropod has important roles to ecosystem, both directly and indirectly [4]. Absent of some arthropod in an ecosystem indicate that this ecosystem was disturbed and never reach 
balance condition. Importance roles of arthropods in ecosystem are as pollinator, decomposer, predator, parasitoid, and as bioindicator for some specific ecosystem health [3]. Ground arthropods have an important role in decomposition of organic matter in ecosystem. Aim of this research is to know about composition, community structure, and survival of ground Arthropod in restoration area in TPA WET.

\section{MATERIALS AND METHODS}

\section{Study Site}

This research was done on July 2015 at Talangagung edutourism landfill (TPA WET), Kepanjen District, Malang Regency, East Java. Identification of Arthropod was conducted in Laboratorium of Ecology and Animal Diversity, Biology Departement, Faculty of Mathematic and Science, University of Brawijaya. TPA WET is one of landfill in Malang Regency with an area of 2.5 ha and can accommodate waste from eight districts in Malang Regency. TPA WET is located on $8^{\circ} 07^{\prime} 13,64^{\prime \prime} S$ and $112^{\circ} 33^{\prime} 44,82^{\prime \prime} E$ and administratively located on Talangagung Village, Kepanjen District, Malang Regency (Fig. 1).

\section{Data Collection}

Arthropod survey was done with four methods, i.e. yellow pan trap, pit fall trap, berlesetullgren, and sweep net. Yellow pan trap's method was used 12 yellow pans and located behind bush to camuflase it [5]. Whereas fit fall trap method used eight jam bottles which filled with detergent and alcohol liquid and wait until three hours to collect the Arthropods. Berlesetullgreen's method was conducted on laboratorium with soil sample from every site. Soil sample was put on funnel, after that its covered with another funnel with electric lamp and in the end of the soil funnel was put a bottle with formalin 5\% to durable the Arthropods. Berlesetullgreen is a method to survey soil mesofauna [6]. Sweep net is method that conducted with swept the net around the location.

\section{Survey and Data Analysis}

Survey was done on four location with twice repetition in every location. Survey locataion was divided to three zone. Zone one with 10 years restoration, zone two with five years restoration, and zone three with not yet restored or still used as an open dumping area, and a reference site. Abiotic factors which collected in this research are light intensity, humidity, and air temperature. Analysis of Arthropod community structure and diversity in every site was obtained from importance value index (IVI) and diversity index (Shannon Wienner Index).

\section{RESULTS AND DISCUSSION Arthropod in TPA WET}

Ground Arthropods was surveyed on four zone, zone one (10 years restoration), zone two (five years restoration), zone three (open dumping area), and reference site. Some Arthropod which found in TPA WET is familly Acrididae, Carabidae, Culicidae, Formi-cidae, Myrmicidae, Gryllidae, Specidae, etc (Fig. 2).

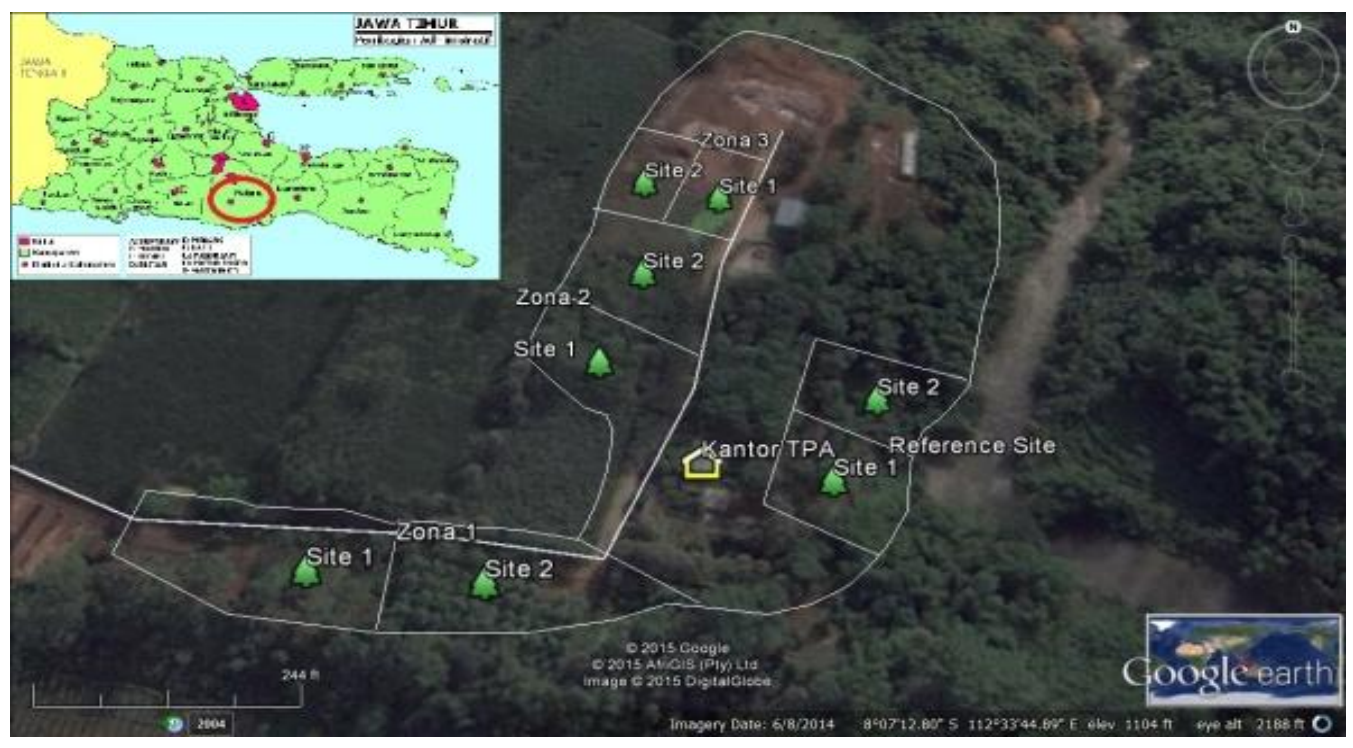

Figure 1. Map of observation site in Talangagung village (Google earth, 2014) 

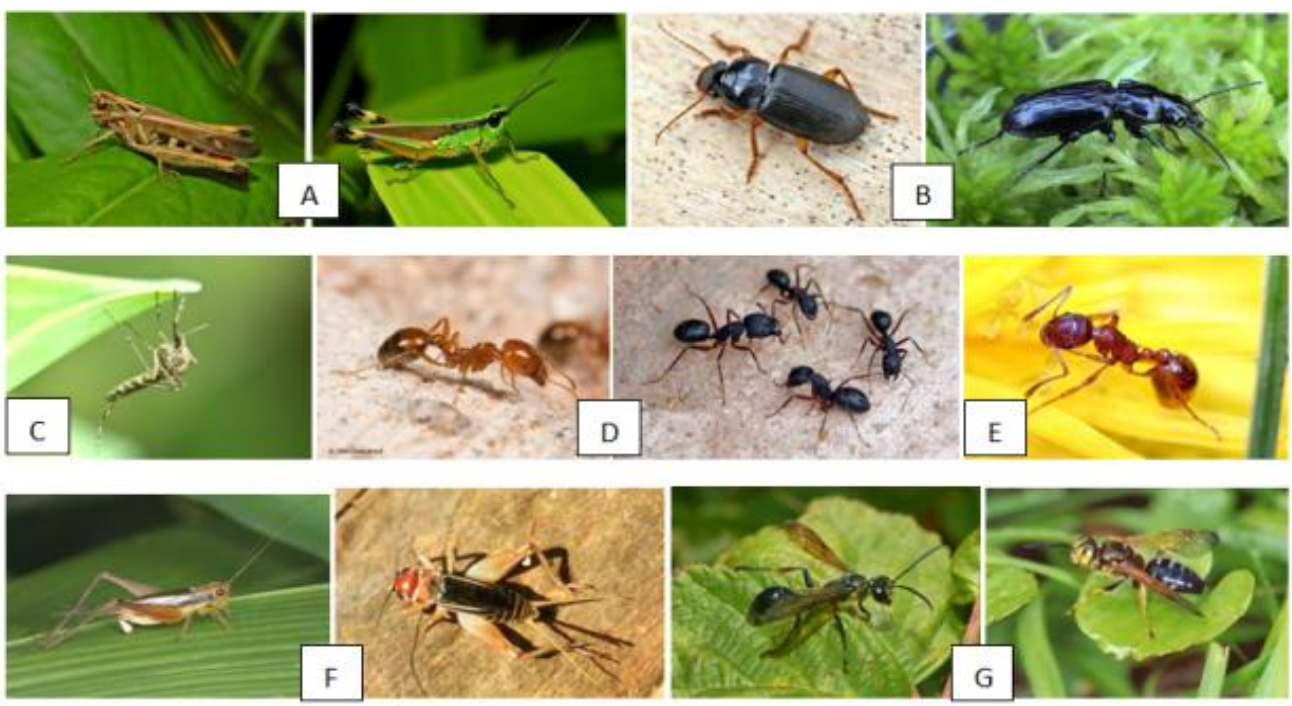

Figure 2. Arthropod family which found in TPA WET

Description: A. Acrididae, B. Carabidae, C. Culicidae, D. Formicidae, E. Myrmicidae, F. Gryllidae, G. Specidae.

Ground Arthropod have some important roles on food chain, especially as decomposer of organic matter in ecosystem. In addition, some arthropods is prey for another Arthropods to maintain Arthropod's sustainability. Arthropod community structure represent the abiotic factor which affected the soil condition and human activity around the location. In this research, Arthdopods can be used as indicator of restoration program in TPA WET.

Some family of Arthropods was dominated some zone. In zone one, Formicidae has the highest species abundance, while in zone two and three dominated by Acrididae. This is due to the location between zone two and three were closed thus both has similar Arthropods community structure. Otherwise, in reference site, Myrmicidae has the highest abundance. Population growth is affected by availability and variability of food source in every habitat [7].

\section{Abundance}

Arthropods abundance in some habitat was affected by diversity and availability of food source on that habitat [8]. Importance value index (IVI) showed an influence of Arthropods family to structure community in each zone (Fig. 3). Dominant family is a family which have IVI > $10 \%$. Zone one has Formicidae as dominant family with $48.6 \%$, while zone two and three has Acrididae as dominant family with IVI $53.5 \%$ and $67.2 \%$, respectively. Myrmicidae is dominant family with $51.4 \%$ in reference site.
Ground Arthropods as a biotic component in ecosystem which dependent on environment factors. Change in environmental influence to presence and density of Arhtopods population. Density of ground Arthropods is affected by physic-chemistry soil factors. Diversity of ground arthropods is lower in disturbed area rather than in undisturbed area. Zone three in this research has the lowest arthropods diversity than other zone because zone three is an area with open dumping which disturb soil condition on that site.

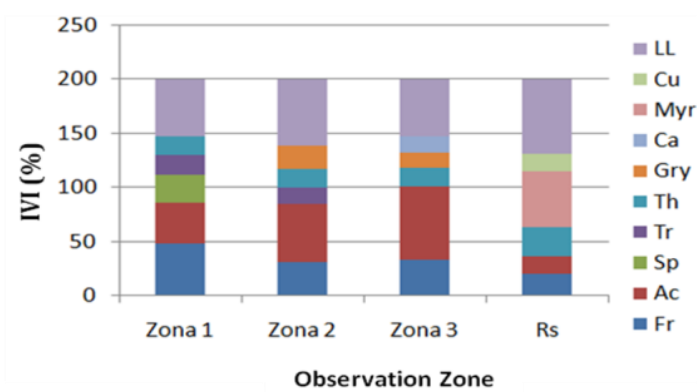

Figure 3. IVI of Arthropods in TPA WET Description: $\mathrm{Fr}=$ Formicidae $\quad$ Ac=Acrididae $\mathrm{Sp}=$ Sphecidae $\quad \mathrm{Tr}=$ Trichogrammatidae Th=Thomicidae $\quad$ Gry=Gryllidae $\mathrm{Ca}=$ Carabidae $\quad$ Myr=Myrmicidae $\mathrm{Cu}=$ Culicidae $\mathrm{LL}=$ others, Zona $1=10$ year restoration Zona $2=5$ year restoration Zona $3=0$ year restoration Rs= Reference site 
Ground Arthropods composition is affected by vegetation composition. Revegetation in zone one was done as 10 years and consist of some trees like Samanea saman Jacq and ground cover plants like Axonopus compresus. Vegetation composition in zone two is dominated by bushes and clump because restoration was conducted 5 years. Zone three is dominated by bushes and no trees, its make this area have no shade for ground Arthropods. In reference site, the vegetation is natural and dominanted by bushes, clump, and trees, especially Bambusasp. Presence of vegetation in some habitat give an ecological services to the animal which live there, as home, food source, and shading area. Change in community and vegetation composition in ecosystem have undirect effect to animal composition and vice versa.

\section{Species Richness}

Zone with the highest species richness is zone two with 16 species was found, followed by zone two and reference site with 14 species, and zone one with 13 species (Fig. 4). The highest species richness in zone two because of high diversity vegetation composition from bush and clump. Vegetation composition in zone two is dominated by Imperata cylindrica, Galinsoga parviflora, and Samenea saman.

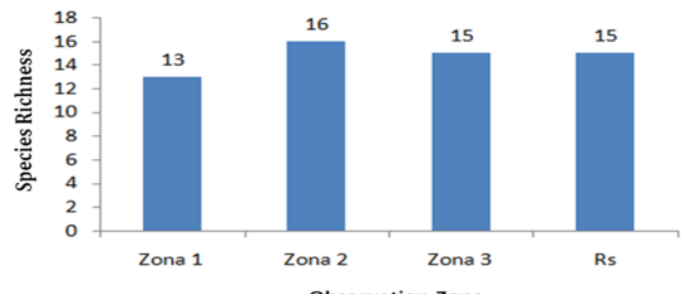

Figure 4. Species richness in every zone of TPA WET Description:

Zona $1=10$ year restoration

Zona $2=5$ year restoration Zona $3=0$ year restoration Rs= Reference site

Arthropods diversity based on diversity index Shannon Wienner showed differences in every zone. The highest diversity index was found in reference site (2.08) which categorized as medium, and in zone one which 10 years restored (1.90), zone two which 5 years restored (1.87), and zone three which still used as open dumping area (1.71) (Fig. 5). It indicates that there were some improvements of environmental quality by restoration programme, where the longest restoration has the best environmental quality [9].

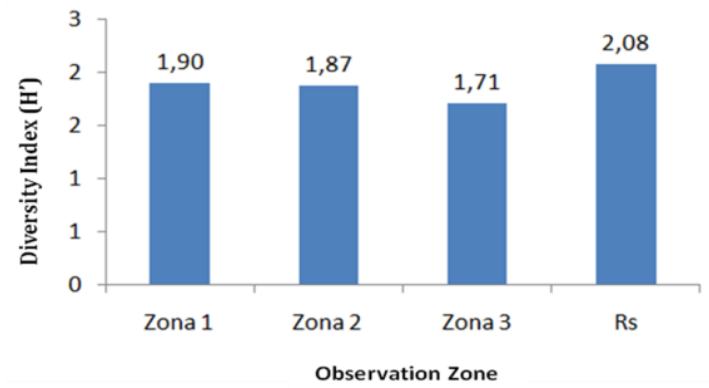

Figure 5. Diversity Index $\left(H^{\prime}\right)$ in every zone based on Shannon Wiener Index Description: Zona $1=10$ year restoration Zona $2=5$ year restoration Zona $3=0$ year restoration Rs= Reference site

The diversity of Arthropods in each family of every zone was affected by resource which provide by environmental. In zone two and three which dominated by grasses was found Miridae and Mantidae. The exsistence of this species make Acrididae which is a predator can dominate the site. Predators is a group of organisme which have generalism feeding pattern, which can adapted to a habitat that has poor resources [10].

\section{Cluster Analysis}

Cluster analysis from IVI, diversity index, abiotic factor, was devided research zone into two cluster, which zone one and reference site in first cluster and zone two and zone three in second cluster (Fig. 6). Its affected by environmental factors that has influences to diversity of arthropods in every zone (Fig. 7).

Reference site was respresented with high organic matter. Number of organic matter in soil can affect to high diversity of ground arthropods [11]. Zone one which represented with high number of Formicidae show that this area has good organic matter. Formicidae is a family of Arthropods that has roles as pollinator, reconditioner of soil degradation, etc. Formicidae is a bioindicator of soil ecosystem health [12].

Reference site represented by high number of Myrmicidae. Presence of Myrmicidae in some area is affected by management factor, soil variation, and agricultural practice [13]. Myrmicidae is an important predator in ecosystem and it is predicted to protect agricultural crops from pests [14]. 
Zone two and three was located in one cluster which characterized with high value of conductivity. It caused by a puddle from waste open dumping system in this area. Moreover, zone two and three represented by high number of some family like Acrididae, Gryllidae, and Carabidae. It indicates that this area was

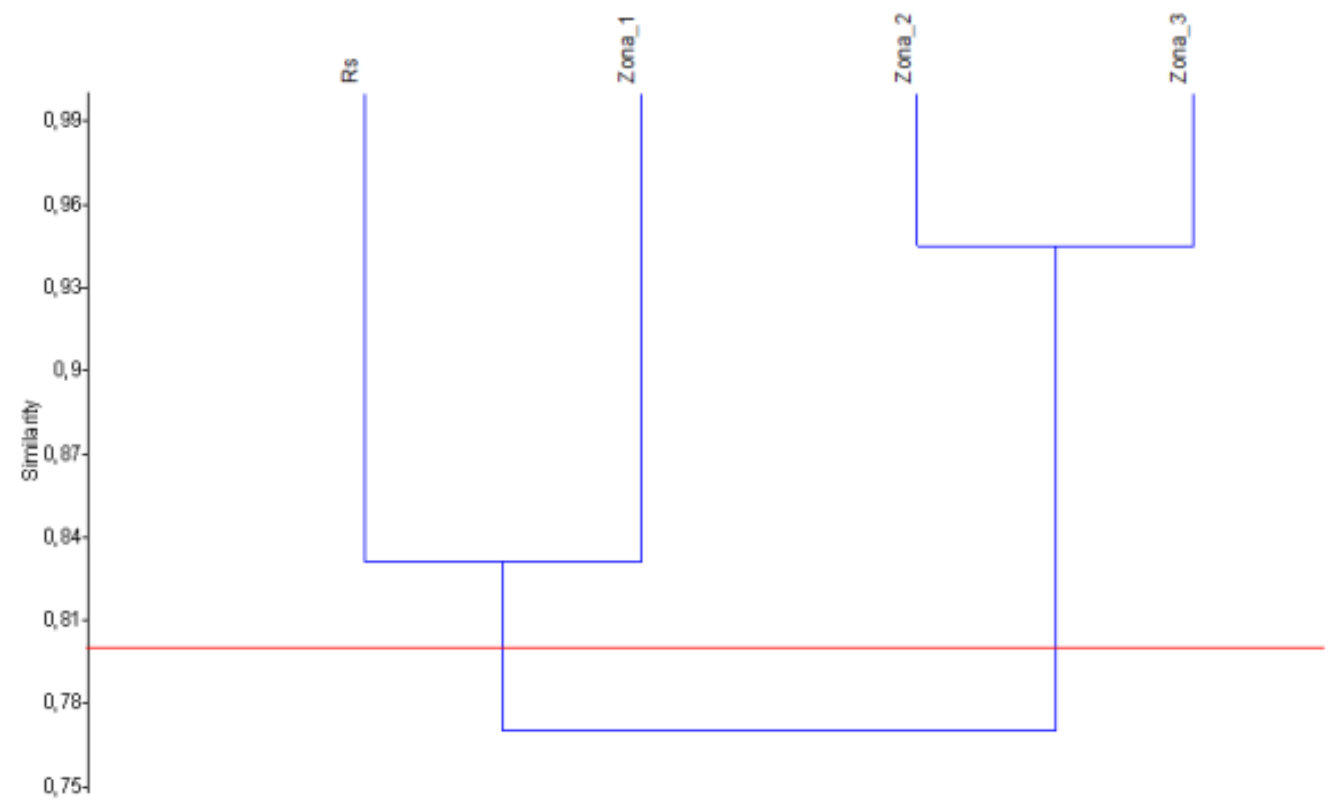

Figure 6. Cluster analysis IVI, $\mathrm{H}^{\prime}$ and abiotic factor

Description: Zona 1= 10 year restoration; Zona 2= 5 year restoration; Zona 3= 0 year restoration; Rs= Reference site

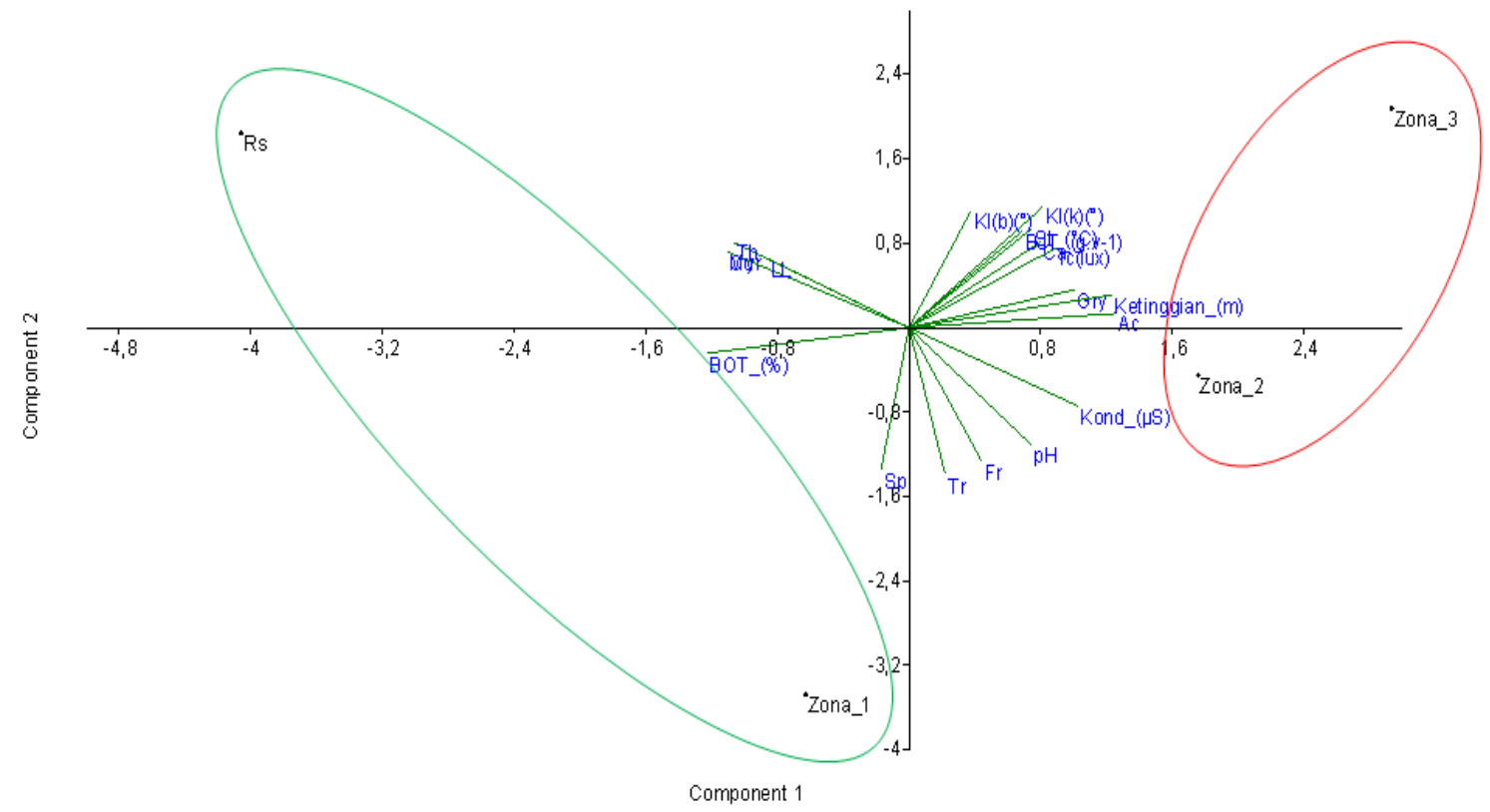

Figure 7. Biplot analysis IVI, $\mathrm{H}^{\prime}$ and abiotic factor

Description: Fr=Formicidae, Ac=Acrididae, $\mathrm{Sp}=\mathrm{Sphecidae,} \mathrm{Tr}=\mathrm{Trich}$ grammatidae, Th=Thomicidae, Gry=Gryllidae, $\mathrm{Ca}=\mathrm{Carabidae}$, Myr=Myrmicidae, $\mathrm{Cu}=$ Culicidaedan $\mathrm{LL}=$ others, Zona $1=10$ year restoration; Zona $2=5$ year restoration; Zona $3=0$ year restoration; Rs= Reference site, $\mathrm{pH}=$ soil pH, Kond $(\mu \mathrm{S})=$ Soil conductivity, Height $(\mathrm{m}), \mathrm{BOT}=$ Soil organic matter $(\%)$, BJT= soil specific gravity $\left([\mathrm{g} . \mathrm{v}) \rrbracket^{\wedge}(-1)\right)$, Ic (lux)=light intensity, $\mathrm{KI}(\mathrm{b})(\%)=$ wet humidity, $\mathrm{KI}(\mathrm{K})(\%)=$ Dry humidity. 
Every group of Arthropod have different response to environmental and climate changes [17]. Grasshoppers and member of Orthoptera family play an important roles to stabilize forest ecosystem [15]. Zone two and three was in a same location separated about $10 \mathrm{~m}$ apart. It make these area was clusterd in same cluster and sharing some resource, migration area, dan home range. Arthropods can move from one area to another to foraging, nesting, or mating [18].
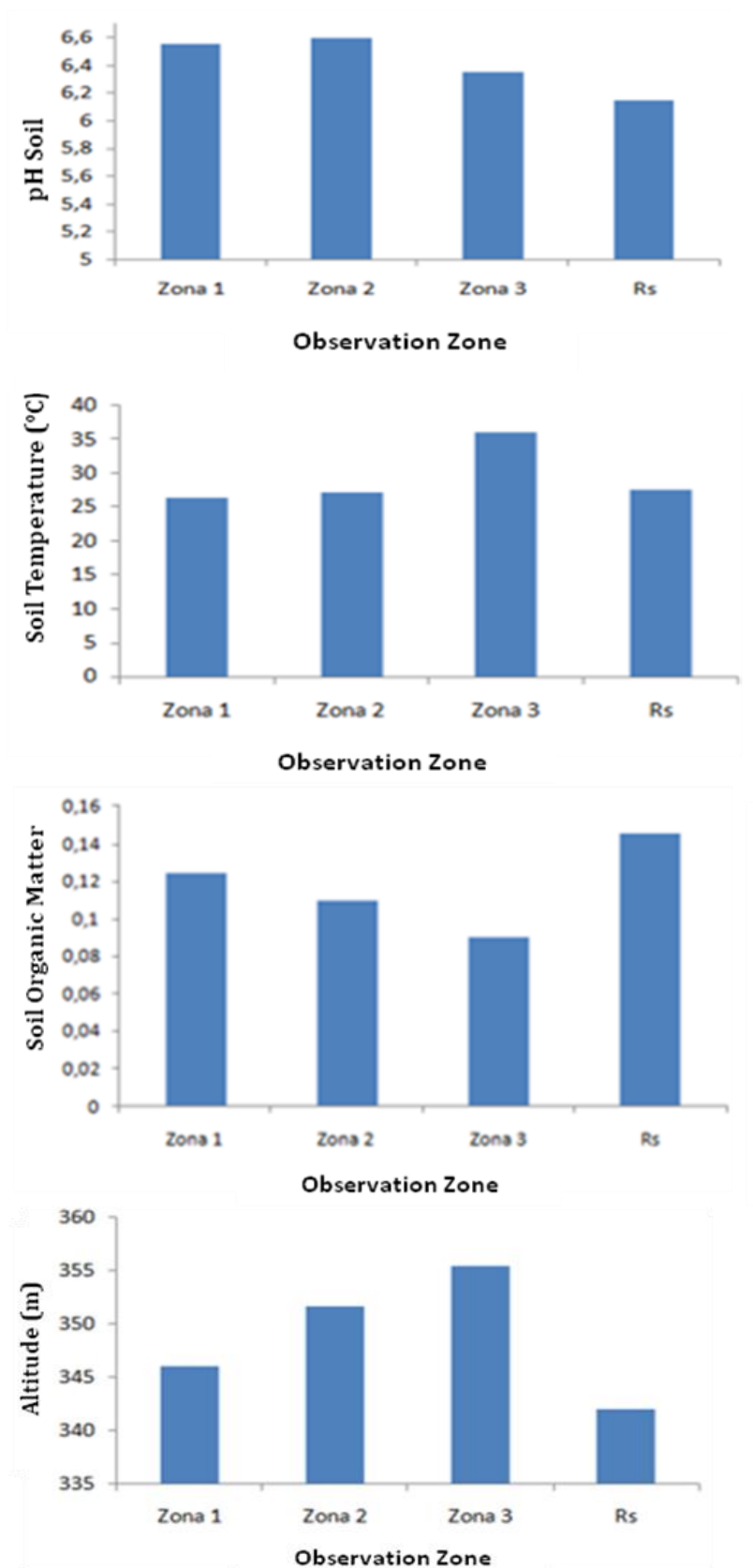

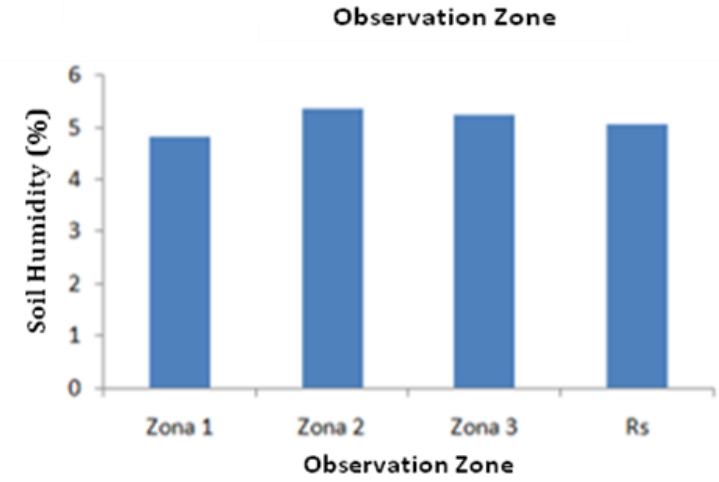

\section{Abiotic Factors}

Abiotic factor in every zone (Fig. 8) was less differences, especially in $\mathrm{pH}$ about 6-7, important factor that influence the presence and abundance of ground Arthropod. Ground Arthropod can live in habitat with high or low acidic level, depend on preferency of Arthropod [19]. Soil conductivity in each zone was low $\left(9-15 \mu \mathrm{S} . \mathrm{cm}^{-1}\right)$. Soil composition is diverse, one of the composition is salt, role as conductor, comparable with the number of electron. Conductivity indicate the ions contained in the soil composition [20].
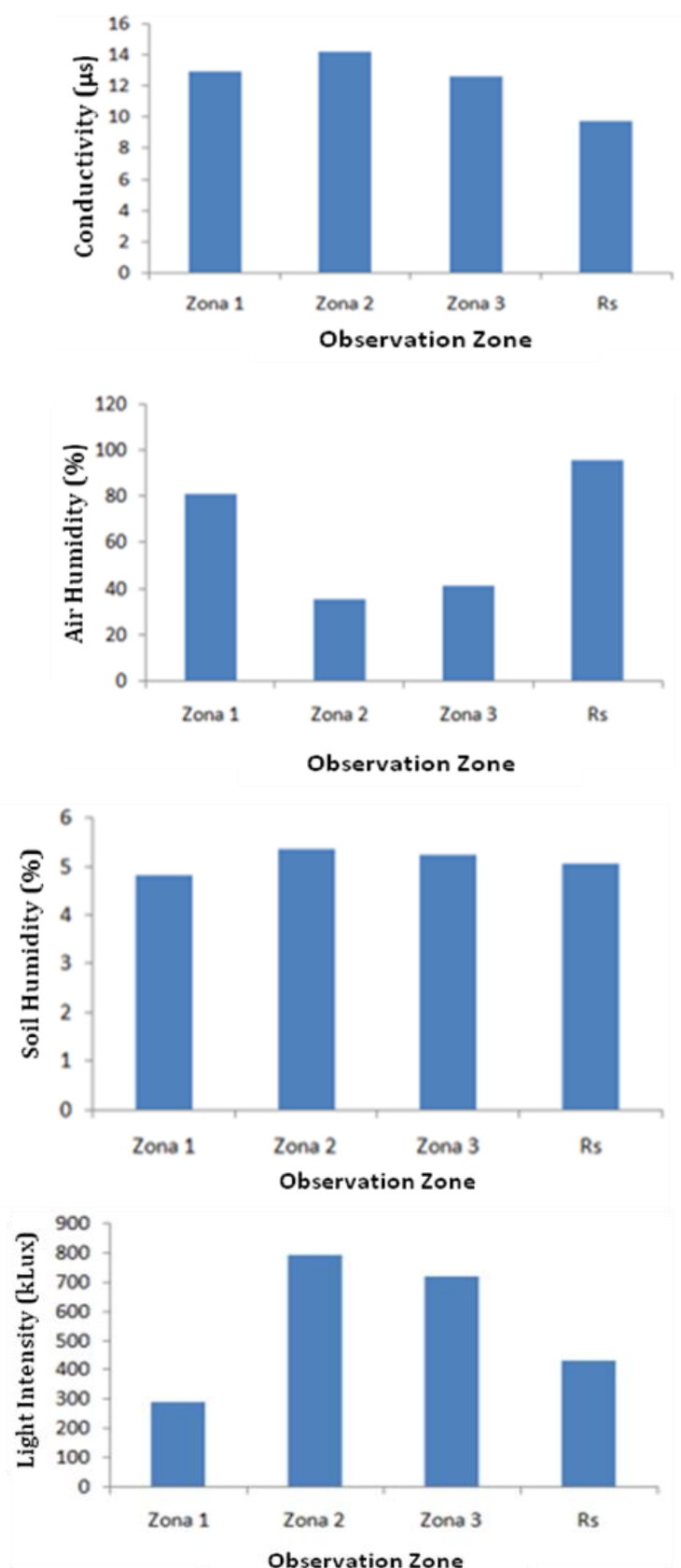

Figure 5. Abiotic factor in every zone in TPA WET

Description: Zona 1= 10 year restoration; Zona 2= 5 year restoration; Zona 3= 0 year restoration; Rs= Reference site 
Light intensity in every zone has different value. Zone two and three has the highest light intencity because this zone has no three canopy, whereas in zone one and reference site has low light intensity. Light intensity has influence the distribution and activities of ground Arthropods. Light intencity is energy source for photoautotrophic component in soil habitat [21]. Altitude level on zone one and reference site is lower than on zone two and three. Physiography factors which influence distribution of organism are altitude and topography of the area. Altitudes has impact to distribution and abundance of soil fauna [22]. It was showed that zone two and three has lower abundance and diversity of ground Arthropods than zone one and reference site.

Humidity is an abiotic important factor that represent moisture content in the area. Excess or deficiency of moisture level will cause some disturbance or damage on some habitat. Based on Anggrainiet al. (2003) relative humidity are comparisons between actual air moisture with the capacity to accommodate water vapor [23]. Wet and dry humidity has the highest level in zone three which has no trees canopy. Zone three is represented with high of soil temperature rather than other site. Soil temperature is an abiotic factor which influence of presence and abundance of soil organism. Soil moisture play roles to level of soil organic matter composition. Soil temperature was affected by air temperature. Air temperature was fluctuatuative in nightday cycle and depend on actual season. The fluctuation of air temperature is also influenced by climate, topography, and soil condition [19].

Organic matters are combination of some organic compound that was composted with decomposition process and some anorganic matter from mineralisation product including heterotrophic and ototrophic microbial. Organic matter can produced from primer sources like organic tissue from flora and seconder source like tissues from fauna, microfauna, and from outside source like organic fertilizer, etc. [24].

\section{CONCLUSION}

Ground Arthropods diversity in zone one, two, three, and reference site is on medium level $(1.90,1.87,1.71,2.08)$. Community structure represented with importance values index (IVI) was dominated by Acrididae in zone two and three with value $67.2 \%$ and $53.5 \%$. Myrmicidae is dominant in reference site with $67.2 \%$, and
Formicidae dominant in zone one with $48.6 \%$. Ground Arthropod in zone one and reference site has close community structure which showed in same cluster, and zone two and three in another cluster.

\section{Acknowledgements}

The authors acknowledge the kindness and cooperation of Luchman Hakim, Ph.D and members of Laboratorium of Ecology and Animal Diversity, University of Brawijaya in revising our manuscript. The authors also thanks Purnomo, S.Si. for his assistence in this study.

\section{REFERENCES}

[1] Bashri, A., B. Utami, and P. R. Primandiri. 2013. Pertumbuhan bibit Trembesi (Samanea saman) dengan inokulasi cendawan Mikoriza Arbuskula pada media bekas Tempat Pembuangan Akhir (TPA). National Seminar XI Biology Education. FKIP. Sebelas Maret University. 11, 165-169.

[2] Nighohossian, C. B. 2014. Arthopod abundance and diversity in restored Longleaf Pine Savannas at Abita Creek Flatwoods Preserve. Thesis. University of New Orleans.

[3] Ardillah, J. S., A. S. Leksono, and L. Hakim. 2014. Diversitas Arthropoda Tanah di Area Restorasi Ranu Pani Kabupaten Lumajang. Jurnal Biotropika 2 (4), 208-213.

[4] Burger, J. C., R. A. Redak, E. Allen, J. T. Rotenberry, and M. F. Allen. 2003. Restoring Arthropod communities in Costal Sage Scrub. Conservation Biology 17 (2), 460-467.

[5] Mazon, M., and S. Bordera. 2008. Effectiveness of two sampling methods used for collecting Ichneumonidae (Hymneptera) in The Cabaneros National Park (Spain). European Journal of Entomology 105, 879888.

[6] Barberena-Arias, M.F., G. Gonzalez, and E. Cuevas. 2003. Quantifying variation of Soil Arthropods using different sampling protocols: is diversity affected? Tropical Forest, 51-70.

[7] Krebs, C. J. 2001. Ecology: the experimental analysis of distribution and abudance $5^{\text {th }} \mathrm{Ed}$. Benjamin Cummings. California.

[8] Saragih, S. E. 2008. Pertanian organisolusi hidup harmoni dan berkelanjutan. Penebar Swadaya. Jakarta.

[9] Rajiyowiyono, H. and S. Suyanto S. 1998. Sifat keteknikan tanah bekas TPA sampah (studi kasus bekas TPA sampah di Kodya 
Surakarta). Buletin Geologi Tata Lingkungan 23 (Juni).

[10] Trisnawati, I. D. T. and T. S. Subhar. 2011. Kelompok trofik pada komunitas Arthropoda tajuk dan tumbuhan inangnya terhadap musim kemarau di daerah beriklim tropis kering Pasuruan dan Malang, Jawa Timur. Berita Biologi 8(3), 193-200.

[11] Sakchoowong, W., S. Nomura, K. Ogata, and J. Chanpaiseng. 2007. Comparison of extraction efficiency between Winkler and Tullgren extractors for Tropical Leaf Litter Macroarthropods. Thai Journal of Agricultural Science 40(3-4), 97-105.

[12] Samudra, F. B., M. Izzati, and H. Pernaweni. 2013. Kelimpahan dan keanekaragaman Arthropoda tanah di lahan sayur organik Urban Farming. Proceeding of National Seminar of Natural and Environment Resources Management. ISBN 978-60217001-1-2 190.

[13] Peck, S. L., B. McQuaid, and C. L. Campbell. 1998. Using Ant species (Hymenoptera: Formicidae) as biological indicator of agroecosystem condition. Environmental Entomology 27, 1102-1110.

[14] Philpott, S. M. and I. Armbrecht. 2006. Biodiversity in tropical agroforest and ecological role of ants and ant diversity in predatory function. Ecological Entomology 31, 369-377.

[15] Erniwati. 2003. Belalang (Orthoptera) dan kekerabatannya. Biodiversity Conservation Project, 63-76.

[16] Kahono, S. and M. Amir. 2003. Ekosistem dan khasanah serangga Taman Nasional Gunung Halimun. Insects of Mount Halimun National Park, West Java. Biodiversity Conservation Project, 1-22.

[17] Kahono, S. 2006. Respon adaptif kumbang Lembing pemakan daun Henosepilachna vigintictopuchtata (Fabricius) (Coleoptera: Coccinellidae: Epilachninae). Biodiversity Conservation Project.

[18] Sutrisno, S. 2008. Penandaan serangga hama dengan Radioisotop untuk studi pola pemencaran, migrasi dan estimasi kepadatan populasi. Jurnal IImiah Aplikasi Isotop dan Radiasi 4 (1), 13-26.

[19] Suin, N. M. 1997. Ekologi hewan tanah. Bumi Aksara. Jakarta.

[20] Atekwana, E. A., R. S. Rowe, D. D. Werkema, and F. D. Legall. 2004. The relationship of total dissolved solids measurements to bulk electrical conductivity in an aquier contami- nated with hydrocarbon. Journal of Applied Geophysics 56, 281-194.

[21] Makalew, A. D. N. 2001. Keanekaragaman biota tanah pada agroekosistem tanpa olah tanah (TOT). Science Phylosophy Paper. Graduate Program, Bogor Agricultural University.

[22] Hermawan, B. 2005. Monitoring kadar air tanah melalui pengukuran sifat dielektrik pada lahan jagung. Jurnal IImu-IImu Pertanian Indonesia 7(1), 15-22.

[23] Anggraini, P. W. K., A. Maddub, and H. R. Anggraini. 2003. Pengaruh kelembaban terhadap absorbansi optik lapisan gelatin. National Seminar I on Opto Electronica and Laser Application. $1^{\text {st }}-2^{\text {nd }}$ October, Jakarta.

[24] Madjid, A. 2007. Bahan organik tanah. Sriwijaya University. Palembang. 